\title{
MICROSTRUCTURE AND GRAIN CHARACTERISTICS OF Ti Nb40 BIOLOGICAL IMPLANT ALLOY Zhu Qifan ${ }^{1, a .{ }^{*}, \text { Sun Zeming, }{ }^{1, b}, \text { Zhang Hongju }{ }^{1,},{ }^{c} H_{\text {Han }} \text { Xiaole }^{1, d}, \text { Yu. P. Sharkee }}{ }^{2, e}$, A. Yu. Eroshenko $2, \mathrm{f}$ \\ 1.General Research Institute for Non-ferrous Metals, Beijing, China \\ 2.Institute of Strength Physics and Materials Science Siberian Branch, RAS, Tomsk, Russia, \\ e-mail:_qiangzhu2222@126.com css1@grinm.com, juju1983cn@yahoo.com.cn
}

Keywords: Biological Implant TiNb alloy micrograin misorientation angle

Abstract. This paper focuses on the development of microstructure of TiNb 40 alloy after severe plastic deformation. Primary billets (blocks) are Ti alloy cast with $40 \% \mathrm{Nb}$ mass which are exposed to a combined two-stages severe plastic deformation method, including abc-pressing and multi-pass rolling in grooved rolls. An area of less than 0.3 micron grains is about $6 \%$ of the total area. It plays a strong role for improving the strength of the material. Microhardness of the alloy increased to $2300 \mathrm{MPa}$. The small-angle grain boundaries (less than $15^{\circ}$ ) of the alloy account for $61.1 \%$ after the combined processing. It is shown that a relatively large amount of micron grains and subgrains were produced in the processing of the alloy.

\section{Introduction}

Titanium alloys more and more respond to modern medical requirements concerning those materials used as implants [1]. However, preferred alloys are those without any toxic alloying elements (A1, V and others) [2]. In this case, the most preferable ones are valve metals of titanium, zirconium and columbium and their alloys. Advanced developments in up-dated implants impose new and new requirements not only in furthering rest-hardening, but also in designing new materials with low elastic modulus level. This, in its turn, allows the distribution of deformation and strain where bone-implant interfaces and excludes possible breakdown at rigid fixation of the implant to the bone. Elastic modulus for most titanium alloys ranges from 100 to $120 \mathrm{GPa}$ and is more than that of bones (15 - $30 \mathrm{GPa}$ ). Accordingly, a perspective domain in medical materials technology is the development of compatible titanium alloys with a rather low elastic modulus module; for example, alloy systems Ti-Nb or Ti-Nb-Zr $[3,4]$. Thus, titanium doping by zirconium or columbium could decrease the elastic modulus up to 55-80 GPa.

Severe plastic deformation methods [5-7] promote the production of ultra-fine grained semi-finished billets (blocks) and products with significantly high mechanical properties in comparison to their coarse-grained analogues. Usually, the nanostructured phase, ultra-fine grain in metals and alloys is attained by combining two or more different intensive plastic deformation methods [5,8-10].

This paper focuses on the development of microstructure of TiNb 40 alloy after a combined two-stages severe plastic processing.

\section{Subjects and experimental procedures}

Primary billets (blocks) are $\mathrm{Ti}$ alloy cast with $40 \% \mathrm{Nb}$ mass. The casting is produced by electric arc-melting [11]. Prior to deformation, titanium alloy samples are tempered at 1100C for 1 hour in argon and further water quenched. During the first stage the samples were deformed by abc-pressing method [8]. For the purpose of a more effective grain refinement, the samples are placed in a press mold during the first two pressing cycles $[9,10]$. Each cycle, at a constant temperature, included 3 -pressing stage with turn-round operation of $90^{\circ}$. In the following cycles, the semi-finished billets (blocks) are deformed in free abc-pressing without grooved rolls. During the second stage, the samples were rolled in grooved to deformation degree of $75-80 \%$ at indoor temperature. Rolling was 
conducted to finite deformation at shrinkage in increments of 2-3\%. After that rolling rods (bars) of are produced. Its dimensions are $6 \times 6 \times 160 \mathrm{~mm}^{3}$. To reduce internal strain and increase elasticity, the rods (bars) are tempered at 300C for 1 hour in argon.

Sample microstructure was investigated by Scanning electronic microscopy JSM-700(JEOL SM-71480). With backscatter diffraction method, grain misorientation angle of the sample, the grain distribution, phase distribution were studied. The microhardness testing of samples in virgin state and after abc-pressing and rolling were conducted in cross-section billets (blocks). Microhardness is measured according to Vickers on microhardness tester Duramin 5.

\section{Results and discussion}

The Phase components of the alloy is shown in Figure 1. The Titanium-niobium 40 alloy is $\beta$ phase alloys. The proportion of $\alpha$ phase accounted in the alloy is $3.3 \%$. As Niobium is a stabilizing element of $\beta$ phase, the component of $\beta$-phase accounted for the vast majority in the alloy. The proportion of $\beta$ phase accounted in the alloy is $96.7 \%$. The grains of $\alpha$-phase are fine and disperse in the boundaries of grain of $\beta$ phase.

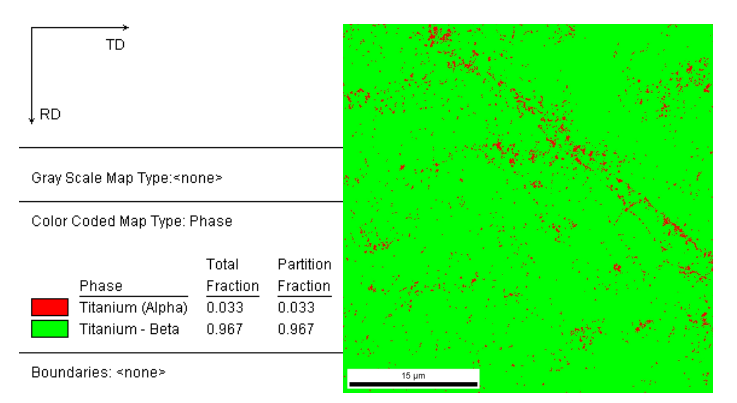

Figure 1. The phase components of the $\mathrm{TiNb} 40$ alloy

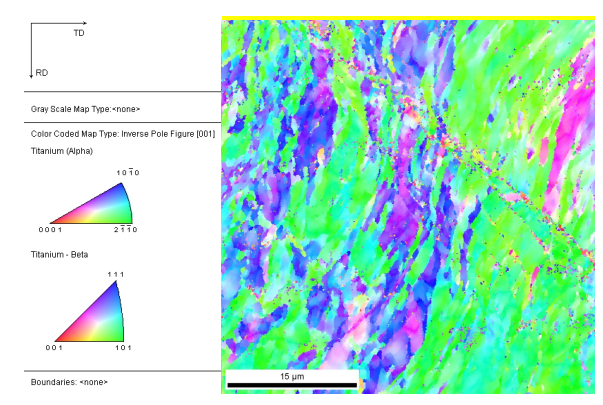

Figure 2. Distribution of the grain misorientation angle and reverse pole figures

After tempering, the micorhardness of the alloy is $1730 \mathrm{MPa}$. The microhardness value increases up to $2300 \mathrm{MPa}$ after abc-pressing and rolling. The backscatter diffraction (EBSD )image and inverse pole figure of the sample were shown in figure 2 , which is taken from the ninth stage of processing of the alloy. The grains misorientation angle are shown out for the processing. From the EBSD images, it's can be observed that there are uneven distribution of misorientation angle. The Shape of the distribution like a strip. This kind of distribution may result changes in performance of the alloy along the edges the textured strips. The distribution of misorientation angle is shown in fig 3. . It can be seen that the small- misorientation angle accounts for a higher proportion. At the grain boundaries, the small-angle grain boundaries occupy a higher proportion. The misorientation angle less than $6.45^{\circ}$ account for $53.8 \%$ of the alloy.

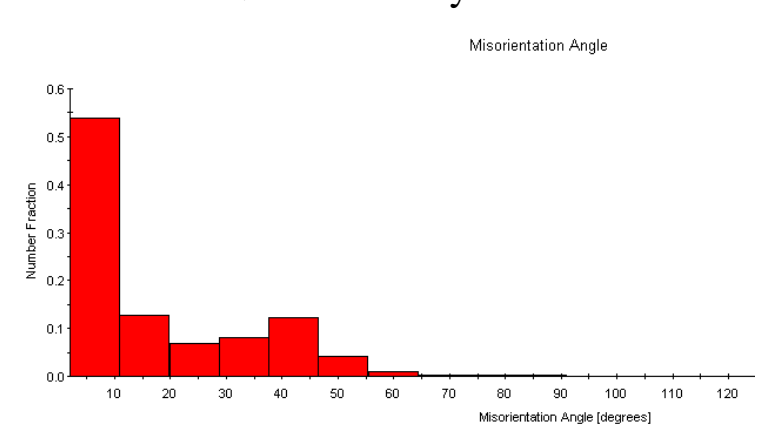

Fig3 . distribution of misorientation angle
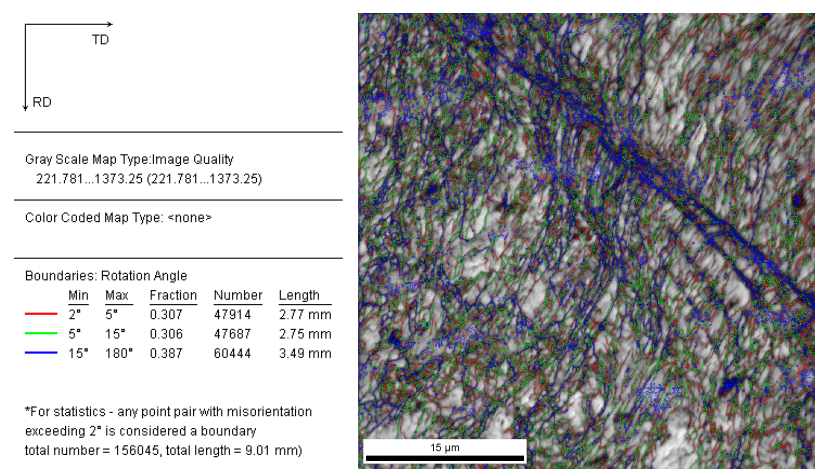

Figure 4. EBSD Metallography and Boundaries rotation angle 
The formation process of microcrystalline and subgrain of TiNb40 alloy can be explained as follows: In the processing of multi-pass strong plastic deformation and rolling of the alloy, the deformation mechanism of TiNb40 alloy was dislocation slipping. At that time, a local shear bands are formed. Grains in the alloy were cut by dislocation slip bands to form sub-grain repeating. Thereafter, the alloy was subjected to a multi-pass of strong plastic deformation again, which leads to the formation of microcrystalline and nano-grains. The end result is that the diameter of particles in $0.3 \mu \mathrm{m}$ or less takes up more than $6 \%$ of total area of the alloy. The distribution of grain size was shown in Fig 5. Microcrystalline in this size ratio play a important role in strengthening alloy. The grains size is less than 1 micron in diameter which accounted for $15 \%$ of the total area. The average size of the structural unit (including grain, sub-grain, debris) is $0.3 \mu \mathrm{m}$. By EBSD method, the grain size of the alloy was measured out accurately. With backscatter diffraction method, The phase diagram of the alloy was obtained. Twinning and small-angle grain boundaries (can not be appearing etching method) can be clearly observed. Metallography of the alloy is shown in figure 4. by EBSD method . Structural fragmentation of the alloy, many local deformation bands (Figure 4.) and sub-grain formation were caused by the $\mathrm{ABC}$ - pressing. Grains in the alloy were lengthen along the direction of the axis of deformation. At $500-400{ }^{\circ} \mathrm{C} \mathrm{ABC}$ repression, it is clear that slip is the mechanism of deformation in the alloy . Local shear zone, twins and small-angle grain boundaries were created in meantime.

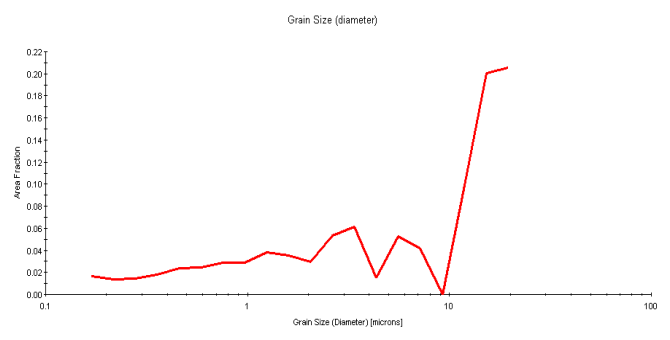

Fig 5 . Distribution of grain size

The distribution of interface angle of grains is shown in Fig.4. The small-angle grain boundaries marked red curve(Less than $2-5^{\circ}$ angle interface) holds $30.5 \%$ of the total grain boundaries. grain boundaries within $5-15^{\circ}$ marked green curve holds $30.6 \%$ of the total grain boundaries. Small-angle grain boundary is less than $15^{\circ}$, which accounted for $61.1 \%$ of the total boundaries. The phenomenon indicate that large amount of subgrain and microcrystalline, nanocrystalline come into being in the processing.

When the samples were subjected to multiple passes of rolling, there are a lot of plastic deformation in the alloy. In backscatter diffraction experiment, there are extinction phenomenon which lead the EBSD pattern blur. This phenomenon indicates that there is a large working stress in sample.

\section{Conclusion}

1. Titanium-niobium40 alloy is $\beta$ phase alloys. $\alpha$-phase grains are small and dispersed in $\beta$-phase grain boundaries.

2. An area of less than 0.3 micron grains is about $6 \%$ of the total area. It plays a strong role for improving the strength of the material. Microhardness value of the alloy increased to $2300 \mathrm{MPa}$ from 1730MPA.

3. Small-angle grain boundaries (less than $15^{\circ}$ ) of $\mathrm{Ti} \mathrm{Nb} 40$ alloy account for $61.1 \%$. It is shown to produce a relatively large amount of microcrystalline and subgrain in the process of he alloy. 


\section{Acknowledgements}

The investigations were supported by the partial financial support of RAS Presidium program in fundamental research, №8, project 21; the Russian Foundation for Fundamental Research (RFFR) program, 2013-2016, project III 23.2.2.

\section{References}

1. S.L.Vasin, Ye.A.Nemets, N.V. Perova i dr. Biosovmestimost /Pod red. V.I.Sevastyanova. - M.: 1999, 368s. (S.L. Vasin, E.A. Hemets, N.V. Perova et.al. Biocompatibility / Ed. V.I. Sevastyanova. M. 1999. P.368).

2. Medical applications of titanium and its alloys: the material and biological issues, American Society for Testing and Materials, USA; 1996, P. 475.

3. Helsen J. A., Breme H.J. (ed) Metals as biomaterials. Chichester, John Wiley and Sons, 1998, 498 p.

4. Mitsuo Niinomi, Masaaki Nakai, Junko Hieda. Development of new metallic alloys for biomedical application // Acta Biomaterialia №8 2012. p.p. 3888-3903.

5. R.Z. Valiyev, I.V. Aleksandrov. Obyemnyye nanostrukturnyye metallicheskiye materialy: polucheniye, struktura i svoystva. M.: IKTs «Akademkniga», 2007.398s.(R.Z. Valiev, I.V. Aleksandrov Volume nanostructure metal materials: production, structure and properties. M. “Akademkniga 2007. P.398).

6. V.M. Segal, V.I. Reznikov, V.I. Kopylov i dr. Protsessy plasticheskogo strukturoobrazovaniya metallov. Minsk: Navuka i tekhnsha, 1994. 232s. (V.M. Segal, V.I. Reznikov, V.I. Konilov, et al. Processes of plastic structure-formation of metals. Minsk: Navuka i tekhnsha. 1994. P. 232).

7. Salishchev G.A., Galeyev R.M., Malysheva S.P., Zherebtsov S.V., Mironov S. Yu., Valiakhmetov O.R., Ivanisenko E.V. Formirovaniye submikrokristallicheskoy struktury v titane i titanovykh splavakh i ikh mekhanicheskiye svoystva // Metallovedeniye i termicheskaya obrabotka metallov. 2006. №2. S.19-26. (G.A. Salischev, R.M. Galeev, S.P.Malisheva, S.V. Zherebtsov, S.Yu. Mironov, O.R. Valiakhmetov, E.V. Ivanisenko Formation of submicrocrystalline structures in titanium and titanium alloys and their mechanical properties. // Metal Science and metal thermal processing. 2006 №2.pp.19-26).

8. A.Yu. Yeroshenko, Yu.P. Sharkeyev, A.I. Tolmachev, G.P. Korobitsyn, V.I. Danilov V.I. Struktura i svoystva obyemnogo ultramelkozernistogo titana, poluchennogo abs-pressovaniyem i prokatkoy // Perspektivnyye materialy. -2009. - Spets. Vypusk.№7. S.107-112.(A.Yu. Eroshenko, Yu. Sharkeyev, A.I. Tolmachev, G.P. Korobistin, V.I. DanilovStructure and properties of volume ultrafine-grained titanium produced by abc-pressing and rolling. J. Advanced materials, 2009. Special issue№7. pp.107-112.

9. Yu.P. Sharkeyev, A.Yu. Yeroshenko, A.D. Bratchikov, Ye.V. Legostayeva, V.I. Danilov, V.A. Kukareko. Obyemnyy ultramelkozernistyy titan s vysokimi mekhanicheskimi svoystvami dlya meditsinskikh implantatov. // Nanotekhnika 2007.№3(11)S.81-88.(Yu.P. Sharkeev, A.Yu. Eroshenko, A.D. Bratchikov, E.V. Legostaeva, V.I. Danilov, V.A. Kukareko. Volume ultrafine-grained titanium with high mechanical properties for medical implants. // Nanotechnology, 2007 №3(11), pp.81-88.

10. Yu.P. Sharkeev, E.V. Legostaeva, A.Yu. Eroshenko, I.A. Khlusov, O.A. Kashin. The Structure and Physical and Mechanical Properties of a Novel Biocomposite Material, Nanostructured Titanium-Calcium-Phosphate Coating // Composite Interfaces. 16 (2009). P. 535-546.

11. Structure property relationship of cast Ti-Nb alloys. C.M. Lee, C.P. Ju, J.H. Chern lin. Journal of Oral Rehabilitation, 2002, №29, 314-322. 